\title{
Pendugaan Umur Simpan Jeruk Siam (Citrus nobilis var. microcarpa) Berdasarkan Kandungan Vitamin C Menggunakan Persamaan Arrhenius
}

\author{
(The Presume of Siamese Orange (Citrus nobilis var. microcarpa) Life Based on the essence \\ of Vitamin $C$ by Using Arrhenius equation)
}

\author{
Niken Wahyuningsih ${ }^{1}$, Ratna $^{1}$, Zulfahrizal ${ }^{1}$ \\ Program Studi Teknik Pertanian, Fakultas Pertanian, Universitas Syiah Kuala
}

\begin{abstract}
Abstrak. Menganalisis mutu selama penyimpanan dapat dilakukan dengan mengendalikan kondisi penyimpanan tertentu serta menduga laju penurunan mutu yang terjadi. Penelitian ini bertujuan untuk menduga umur simpan jeruk siam berdasarkan laju penurunan vitamin $\mathrm{C}$ selama penyimpanan menggunakan persamaan Arrhenius. Jeruk siam segar disimpan dengan variasi suhu yaitu suhu $10{ }^{\circ} \mathrm{C}$, $15^{\circ} \mathrm{C}$, dan $28^{\circ} \mathrm{C}$. Analisis dilakukan 3 hari sekali hingga panelis menolak dengan parameter susut bobot, tingkat kekerasan, total padatan terlarut (TPT), vitamin C, dan uji organoleptik yaitu warna, aroma, tekstur, rasa, dan penerimaan keseluruhan. Hasil penelitian diperoleh persentase susut bobot pada suhu $10^{\circ} \mathrm{C}$ dan suhu $15^{\circ} \mathrm{C}$ yaitu $11,57 \%$ pada penyimpanan hari ke- 12 . Tingkat kekerasan tertinggi pada suhu penyimpanan $10{ }^{\circ} \mathrm{C}$ yaitu $2,09 \mathrm{Kg} / \mathrm{cm} 2$. Suhu $15{ }^{\circ} \mathrm{C}$ mengalami kenaikan total padatan terlarut paling tinggi hingga $9,70 \%$ brix. Uji organoleptik penyimpanan terbaik pada suhu $15{ }^{\circ} \mathrm{C}$ dengan lama penyimpanan hingga hari ke- 12 , warna, tekstur, aroma, rasa dan penerimaan keseluruhan skornya yaitu $4,28,4,05,3,76,4,50$ dan 4,10. Umur simpan jeruk siam pada suhu $10^{\circ} \mathrm{C}$ umur simpannya 15 hari, suhu penyimpanan $15{ }^{\circ} \mathrm{C}$ umur simpannya 14 hari, Suhu $28{ }^{\circ} \mathrm{C}$ umur simpannya 13 hari. Penelitian ini didapatkan model pendugaan laju penurunan mutu jeruk siam selama penyimpanan yaitu $\mathrm{k}=30.01808$ e-777.54(1/T).
\end{abstract}

Kata kunci : Jeruk Siam, Umur Simpan, Vitamin C

Abstract. Analyzing the quality during storage could be done by controlling the storage as well as suspecting the rate of decrease the quality. This research aim to presume the life of siamese orange based on the rate of vitamin $\mathrm{C}$ decrease during the storage by using Arrhenius equation. The fresh siamese oranges with variety of storage temperature were $10{ }^{\circ} \mathrm{C}, 15{ }^{\circ} \mathrm{C}$, and $28{ }^{\circ} \mathrm{C}$. Analysis done in 3 days until the panelist refected to the shrinkage of weight, the level of solid, total soluble solid (TSS), Vitanin C, and organoleptic test such as colour, aroma, texture, taste, acceptance in a whole. From the result it is obtained the percentage of shrinkage weigh of temperature at $10{ }^{\circ} \mathrm{C}$ and at $15{ }^{\circ} \mathrm{C}$ was $11,57 \%$ in the storage of day 12. The highest level of solid was on temperature at $10{ }^{0} \mathrm{C}$ was $2,09 \mathrm{~kg} / \mathrm{cm}^{2}$. On the temperature $15{ }^{\circ} \mathrm{C}$ it has the total soluble solid up to $9,70 \mathrm{~b} \%$ brix. The best organoleptic test storage was on temperature $15^{\circ} \mathrm{C}$ with in 12 days of storage, the highest colour, aroma, texture, taste, and acceptance in a whole score was $4,28,4,05,3,76,4,50$ and 4,10 . The siamese orange life storage on temperature 10 ${ }^{0} \mathrm{C}$ could be storage for 15 days, on temperature $15{ }^{\circ} \mathrm{C}$ could be storage for 14 days, on temperature 28 ${ }^{0} \mathrm{C}$ could be storage for 13 days. The reseach found out that the persume of decreasing the quality of siamese orange duringstorage was $\mathrm{k}=30.01808 \mathrm{e}-777.54(1 / \mathrm{T})$.

Keywords: Siamese orange, presume, Vitamin C 


\section{PENDAHULUAN}

Di Indonesia, dari sejumlah spesies $C$. nobilis dikenal 2 jeruk keprok, yaitu jeruk siam dan jeruk keprok. Jeruk siam termasuk jeruk keprok (Citrus nobilis var. microcarpa) yang mempunyai ciri kulit buahnya tipis, licin mengkilap, menempel lebih lekat pada daging buah hingga kulit dikupas, ukuran buah sedang, bentuknya bulat seperti bola dengan aroma yang tidak begitu tajam. Daerah penanaman jeruk siam umumnyadi dataran rendah (Rahmat dan Yuyun, 2003).

Sifat produk yang mudah rusak setelah dipanen menjadikan tindakan penyimpanan merupakan salah satu bagian penting dari rantai pemasaran yang perlu mendapatkan perhatian. Produsen berupaya memberikan perlakuan di dalam penyimpanan untuk menghambat penurunan mutu bahan serta mencagah kebusukan akibat mikroorganisme. Metode penyimpanan bagaimana yang digunakan sangat tergantung pada jenis produk. Namun demikian, sebagai patokan adalah bahwa produk tersebut dapat diterima oleh konsumen dalam pengertian mutu, kondisi dan penampakan yang memenuhi selera sesudah penyimpanan selama periode waktu tertentu (Zulkarnain,2010).

Suhu merupakan faktor yang berpengaruh terhadap perubahan mutu makanan. Oleh karena itu dalam menduga kecepatan penurunan mutu makanan selama penyimpanan, faktor suhu harus selalu diperhitungkan. Dalam penyimpanan makanan, keadaan suhu ruangan penyimpanan selayaknya dan keadaan tetap dari waktu ke waktu tetapi sering kali keadaan suhu penyimpanan berubah - ubah dari waktu ke waktu. Apabila keadaan suhu penyimpanan tetap dari waktu ke waktu ( atau dianggap tetap ) maka perumusan masalahnya biasa sederhana, yaitu laju penurunan mutu cukup dengan menggunakan persamaan Arhenius (Syarief dan Halid, 1993).

Model Arrehnius pada umumnya digunakan untuk menduga umur simpan produk pangan yang kerusakannya banyak dipengaruhi oleh perubahan suhu, yaitu dengan memicu terjadinya reaksi-reaksi kimia yang berkontribusi pada kerusakan produk pangan. Pendugaan umur simpan model Arrhenius dapat dilakukan dengan menyimpan produk pangan pada suhu ekstrim dimana kerusakan produk pangan tersebut dapat lebih cepat terjadi (Kusnandar, 2006).

\section{METODE PENELITIAN}

Penelitian ini dilaksanakan di Laboratorium Teknik Pasca Panen, Program Studi Teknik Pertanian, Fakultas Pertanian, Universitas Syiah Kuala, Darussalam, Banda Aceh, Bulan Maret 2016 sampai Juli 2016

\section{Alat dan Bahan}

Alat-alat yang digunakan dalam penelitian ini adalah timbangan digital, lemari pendingin (Refrigerator), refraktometer merk ATAGO PR-32 $\alpha$, fruithardness tester, wadah/baskom, dan bahan yang digunakan pada penelitian ini adalah jeruk siam yang diperoleh dari petani Desa Bumi Ayu, Kecamatan Timang Gajah, Kabupaten Bener Meriah

\section{Metode Penelitian}

Jeruk siam dilakukan penyimpanan pada suhu $10{ }^{0} \mathrm{C}, 15{ }^{0} \mathrm{C}$ dan $28{ }^{0} \mathrm{C}$. Selama penyimpanan dilakukan pengamatan seperti : Susut bobot, tingkat kekerasan, total padatan terlarut (TPT), vitamin C dan uji organoleptik yaitu warna, aroma, tekstur, rasa dan penerimaan keseluruhan. Untuk pengambilan data dilakukan dengan menganalisis sampel dilaboratorium dalam selang waktu 3 hari penyimpanan. 


\section{Prosedur Pengujian di Laboratorium}

Penelitian ini menggunakan jeruk siam segar dengan variasi suhu penyimpanan yaitu suhu $10^{\circ} \mathrm{C}, 15^{\circ} \mathrm{C}$, dan $28^{\circ} \mathrm{C}$. Analisis dilakukan 3 hari sekali hingga panelis menolak dengan parameter susut bobot, tingkat kekerasan, total padatan terlarut (TPT), vitamin C, dan uji organoleptik yaitu warna, aroma, tekstur, rasa, dan penerimaan keseluruhan. Penelitian ini memprediksi umur simpan jeruk siam menggunakan metode Arrhenius berdasarkan laju penurunan vitamin $C$. Tahapan pertama yang dilakukan adalah dengan menentukan orde reaksi yang diperoleh dari plot persamaan regresi berdasarkan nilai $\mathrm{R}^{2}$ (koefisien determinasi) tertinggi. Setelah orde reaksi ditetapkan maka diperoleh nilai $\mathrm{k}$ dari persamaan regresinya. Untuk simulasinya digunakan persamaan yang diperoleh dari plot hubungan $\ln \mathrm{k}$ dan $1 / \mathrm{T}$.

\section{Susut Bobot}

Penentuan susut bobot, jeruk siam diambil dari tempat penyimpanan dan kemudian ditimbang dengan menggunakan timbangan digital. Sebelumnya timbangan diatur pada posisi 0,00. Kemudian hasil dibandingkan dengan berat jeruk siam pada hari pertama. Penyusutan bobot jeruk siam dinyatakan dalam prosentase berat (\%) yang diukur setiap 3 hari sekali selama penyimpanan dan mengalami peningkatan susut setiap dilakukan pengukuran

\section{Kekerasan}

Pada penelitian ini pengukuran kekerasan jeruk siam menggunakan Fruit Hardness Tester No.510-5 FHR-5 buatan Jepang. Prinsip kerjanya yaitu dengan menentukan besarnya tekanan yang diperlukan untuk dapat dimasukkan alat penekan kedalam buah jeruk siam sampai batas tertentu.

\section{Total Padatan Terlarut}

Total padatan terlarut (\%) dihitung dengan mengunakan Refraktometer ATAGO PR-32 $\alpha$ buatan Amerika. Cara kerjanya adalah alat dibersihkan terlebih dahulu dengan alcohol dan dikeringkan dengan tisu kemudian setetes sampel diletakkan pada prisma refraktometer yang sudah distabilkan pada suhu tertentu, lalu dilakukan pembacaan. Nilai TPT ditunjukkan oleh angka yang didapat pada batas garis biru dan biru. Total padatan terlarut dinyatakan dalam \% brix.

\section{Ornoleptik}

Pengujian organoleptik/sensorik dapat ditentukan dengan menggunakan indera manusia (secara visual). Selang angka (skor) yang digunakan dalam skala hedonik ini terdiri atas lima tingkat kesukaan, yaitu: $1=$ sangat tidak suka, $2=$ tidak suka $3=$ biasa saja, $4=$ suka, $5=$ sangat suka. Dengan parameter kritisnya dilihat berdasarkan warna, tekstur, dan bentuk (Kesegaran).

\section{Vitamin C}

Kadar Vitamin C dapat ditentukan dengan titrasi iodin. Hal ini berdasarkan sifat bahwa Vitamin $\mathrm{C}$ dapat bereaksi dengan iodin. Filtrat sebanyak $25 \mathrm{ml}$ dititrasi dengan larutan iod $0,01 \mathrm{~N}$, sebelum dititrasi ditambahkan indikator amilum pada filtrat tersebut. Titrasi dilakukan sampai terjadi perubahan warna yang stabil (ditandai dengan terbentuknya warna biru kehitaman). 


\section{Analisa Statistik}

Pengujian untuk laju reaksi pada perubahan kadar air jeruk siam selama pengolahan dengan menggunakan metode Accerelerated Shelf Life Testing (ASLT) dengan pendekatan persamaan Arhenius untuk memperhitungkan perubahan energi aktivasi. Tahapan pertama yang dilakukan adalah dengan menentukan orde reaksi yang diperoleh dari plot persamaan regresi berdasarkan nilai $\mathrm{R}^{2}$ (koefisien determinasi) tertinggi. Setelah orde reaksi ditetapkan maka diperoleh nilai $\mathrm{k}$ dari persamaan regresinya. Untuk simulasinya digunakan persamaan yang diperoleh dari plot hubungan ln $\mathrm{k}$ dan 1/T.

\section{Susut Bobot}

\section{HASIL DAN PEMBAHASAN}

Berdasarkan data penelitian yang telah diperoleh, bahwa susut bobot pada jeruk siam mengalami peningkatan seiring lamanya penyimpanan. Persentase susut bobot tertinggi dialami oleh jeruk siam yang disimpan pada suhu dingin $10^{\circ} \mathrm{C}$ dan suhu $15^{\circ} \mathrm{C}$ yaitu $11,57 \%$ pada penyimpanan hari ke- 12. Setelah hari ke-12 jeruk siam tidak lagi dianalisis karena sudah ditolak oleh panelis saat uji organoleptik seperti yang dapat dilihat pada Tabel 1 .

Penyusutan susut bobot selama penyimpanan dingin dapat disebabkan karena kelembaban yang ada pada bahan meninggalkan permukaan bahan dan menuju ke udara disekitarnya melalui proses kondensasi uap air (Fellow, 2000). Setiap komoditi memiliki laju transpirasi yang berbeda walaupun disimpan pada kondisi yang sama. Hal ini disebabkan karena adanya perbedaan permukaan komoditi yang disimpan. Selain luas permukaan komoditi, sifat alami permukaan kulit komoditi juga mempengaruhi laju transpirasi.

Tabel 1. Susut bobot jeruk siam dengan variasi suhu penyimpanan

\begin{tabular}{|c|c|c|c|}
\hline \multirow{2}{*}{ Hari Penyimpanan } & \multicolumn{3}{|c|}{ Variasi Suhu Penyimpanan } \\
\cline { 2 - 4 } & Suhu $10{ }^{\circ} \mathrm{C}$ & Suhu $15^{\circ} \mathrm{C}$ & Suhu $28{ }^{\circ} \mathrm{C}$ \\
\hline Hari 0 & 0 & 0 & 0 \\
\hline Hari 3 & 3,24 & 3,94 & 0,46 \\
\hline Hari 6 & 6,25 & 7,41 & 0,93 \\
\hline Hari 9 & 9,03 & 9,72 & 1,62 \\
\hline Hari 12 & 11,57 & 11,57 & 2,31 \\
\hline
\end{tabular}

\section{Kekerasan}

Tingkat kekerasan jeruk siam pada hari ke-12 diketahui bahwa tingkat kekerasan tertinggi pada suhu penyimpanan $10{ }^{\circ} \mathrm{C}$ yaitu $2,09 \mathrm{Kg} / \mathrm{cm}^{2}$ Data tingkat kekerasan dapat dilihat pada Tabel 2.

Tabel 2. Tingkat kekerasan jeruk siam dengan variasi suhu penyimpanan

\begin{tabular}{|c|c|c|c|}
\hline \multirow{2}{*}{ Hari Penyimpanan } & \multicolumn{3}{|c|}{ Variasi Suhu Penyimpanan } \\
\cline { 2 - 4 } & Suhu $10{ }^{\circ} \mathrm{C}$ & Suhu $15{ }^{\circ} \mathrm{C}$ & Suhu $28{ }^{\circ} \mathrm{C}$ \\
\hline Hari 0 & 2,25 & 2,26 & 2,23 \\
\hline Hari 3 & 2,20 & 2,22 & 2,19 \\
\hline Hari 6 & 2,11 & 2,17 & 2,05 \\
\hline Hari 9 & 2,06 & 2,11 & 1,97 \\
\hline Hari 12 & 2,09 & 2,06 & 1,91 \\
\hline
\end{tabular}


Kehilangan air pada suatu produk merupakan penyebab utama kerusakan produk karena selain berpengaruh langsung terhadap susut bobot, tetapi juga menyebabkan penurunan kualitas penampilannya karena layu dan pengkerutan tekstur menjadi lunak, lembek, serta turunnya nutrisi dari produk buah jeruk siam. Hal ini sesuai dengan pendapat Syarief dkk (1989) bahwa tingkat suhu tertentu dan fluktuasi suhu sangat mempengaruhi mutu produk.

\section{Total Padatan Terlarut}

Salah satu perubahan nyata pada penyimpanan jeruk siam adalah kandungan total padatan terlarut yang sering disebut juga dengan kadar gula total yang menunjukkan kandungan gula yang terdapat pada bahan tersebut. Tabel 3 menyajikan data rerata prosentase total padatan terlarut setelah perlakuan penyimpanan jeruk siam pada suhu $28{ }^{\circ} \mathrm{C}, 15^{\circ} \mathrm{C}$, dan $10{ }^{\circ} \mathrm{C}$.

Tabel 3. Total padatan terlarut jeruk siam dengan variasi suhu penyimpanan

\begin{tabular}{|c|c|c|c|}
\hline \multirow{2}{*}{ Hari Penyimpanan } & \multicolumn{3}{|c|}{ Variasi Suhu Penyimpanan } \\
\cline { 2 - 4 } & Suhu $10^{\circ} \mathrm{C}$ & Suhu $15^{\circ} \mathrm{C}$ & Suhu $28{ }^{\circ} \mathrm{C}$ \\
\hline Hari 0 & 6,9 & 6,9 & 6,9 \\
\hline Hari 3 & 7,2 & 7,3 & 7,0 \\
\hline Hari 6 & 7,6 & 7,6 & 7,3 \\
\hline Hari 9 & 8,7 & 8,1 & 8,0 \\
\hline
\end{tabular}

Hasil analisis total padatan terlarut menunjukkan bahwa nilai untuk ketiga suhu mengalami kenaikan tingkat total padatan terlarut di hari ke- 12 seperti pada suhu $15{ }^{0} \mathrm{C}$ mengalami kenaikan total padatan terlarut hingga 9,70\% BRIX. Namun kenaikan hanya bertahan pada hari ke- 12 lambat laun kadar TPT jeruk siam mengalami penurunan. Hal ini disebabkan karena adanya proses pemecahan polisakarida menjadi gula (sukrosa, glukosa, fruktosa) yang terjadi saat penyimpanan. Setelah mengalami kenaikan lambat laun kadar gula pada jeruk siam menjadi menurun. Penurunan tersebut dikarenakan cadangan polisakarida yang terbentuk tinggal sedikit. Sesuai dengan pernyataan (Helmiyesi dkk., 2008) bahwa lama penyimpanan berpengaruh terhadap kadar gula yang terkandung pada buah jeruk siam.

\section{Organoleptik \\ Warna}

uji organoleptik pada hari ke-0 jeruk siam masih terlihat segar dengan warna kuning kehijauan dan masih bisa diterima panelis. Jeruk siam yang disimpan pada suhu $10{ }^{\circ} \mathrm{C}$ warna kulitnya semakin menguning namun hingga hari ke-12 kulit buah semakin mengkerut dengan skor yaitu 3,30 (biasa saja). Pada suhu $15{ }^{\circ} \mathrm{C}$ warna jeruk semakin menguning hingga sangat kuning dengan skor yang di dapat 4.28 (suka) namun masih mempertahankan kesegaran warnanya. Peningkatan warna jeruk semakin menguning dialami juga untuk jeruk siam yang disimpan pada suhu $28{ }^{\circ} \mathrm{C}$ yaitu 3,45 (biasa saja). Berdasarkan penampakan warna jeruk siam yang disimpan pada suhu $28{ }^{\circ} \mathrm{C}$ semakin menguning sampai penyimpanan 12 hari sedangkan buah jeruk yang disimpan pada suhu $15{ }^{\circ} \mathrm{C}$ terlihat masih dapat dipertahankan kesegaran warna buah jerukHal ini dikarenakan suhu rendah menyebabkan proses degradasi khlorofil selama penyimpanan berjalan lebih lambat. Menurut kader (1992) suhu penyimpanan adalah faktor utama yang mempengaruhi terjadinya degradasi khlorofil.

\section{Tekstur}


Uji organoleptik penyimpanan terbaik pada suhu $15{ }^{\circ} \mathrm{C}$ dengan lama penyimpanan hingga hari ke- 12, tingkat kesukaan panelis tekstur jeruk siam nilainya 4,05 (suka). Salah satu penyebab terjadinya kerusakan produk adalah penguapan kandungan air dalam produk sehingga terjadi pengkerutan pada kulit jeruk siam, buah menjadi busuk karena juga dapat menyebabkan penurunan kualitas penampilannya, sehingga menyebabkan mutu produk bahan pangan mengalami penurunan secara fisik atau teksturnya.

\section{Aroma}

Hasil uji organoleptik terhadap aroma jeruk siam yang disimpan dengan variasi suhu penyimpanan hari menunjukan tingkat ketidak sukaan panelis cenderung meningkat dengan semakin lamanya hari penyimpanan. Aroma untuk jeruk siam yang disimpan pada suhu $10{ }^{\circ} \mathrm{C}$ dan $15{ }^{\circ} \mathrm{C}$ masih dapat diterima panelis pada hari ke-12, jeruk siam dengan suhu penyimpanan 10 0C dengan nilai 3,50 (biasa saja) dan pada suhu $15{ }^{\circ} \mathrm{C}$ dengan nilai 3,76 (suka), untuk penyimpanan jeruk siam suhu $280 \mathrm{C}$ skor nilai yang diberikan oleh panelis yaitu 3.16 (biasa saja).

\section{Rasa}

rasa untuk buah jeruk suhu $10{ }^{\circ} \mathrm{C}$ dan $15{ }^{\circ} \mathrm{C}$ nilai uji organoleptik rasa dari buah jeruk siam semakin meningkat hingga hari ke-12, untuk penyimpanan suhu $10{ }^{\circ} \mathrm{C}$ adalah 4,05 (suka) dan suhu $15{ }^{\circ} \mathrm{C}$ adalah 4,50 (suka). Untuk suhu $28{ }^{\circ} \mathrm{C}$ nilai organoleptik rasa semakin meningkat dengan skor nilai adalah 4,50 (suka). Setelah hari ke- 12 lambat laun terjadi penurunan skor atau nilai rasa untuk jeruk siam yang disimpan dengan variasi perlakuan suhu $10{ }^{\circ} \mathrm{C}, 15{ }^{\circ} \mathrm{C}$ dan $28{ }^{\circ} \mathrm{C}$.

Perubahan sifat kimia pada jeruk siam yang terjadi adalah perubahan rasa manis pada jeruk siam yang ditunjukkan melalui total padatan terlarut (TPT). Kecenderungan yang bisa terjadi pada buah selama penyimpanan adalah terjadi kenaikan kandungan TPT yang kemudian disusul dengan penurunan. Pada organoleptik rasa menunjukkan hal yang sama bahwa rasa buah jeruk siam semakin manis namun kembudian lambat laun rasa tersebur menurun seiring lamanya penyimpanan.

\section{Penerimaan Keseluruhan}

Penerimaan keseluruhan merupakan hasil panelis yang memberi skor terhadap warna, tekstur, aroma, dan rasa. Uji organoleptik penerimaan keseluruhan dapat menyimpulkan dari semua variasi perlakuan suhu penyimpanan yang terbaik untuk digunakan dalam penyimpaan jeruk simpan. Penilaian organoleptik terhadap penerimaan keseluruhan cenderung mengalami penurunan selama penyimpanan.

Nilai organoleptik penerimaan keseluruhan untuk jeruk siam dengan suhu $15{ }^{\circ} \mathrm{C}$ nilai skala organoleptik paling bagus yang diberikan 4,10 (suka) dan untuk suhu $10{ }^{\circ} \mathrm{C}$ skala organoleptinya yaitu 3,30 (biasa saja). Sedangkan penyimpanan jeruk siam suhu $28{ }^{0} \mathrm{C}$ penilaian organoleptik penerimaan keseluruhan yang paling tidak bagus diberikan 3,05 (biasa saja)

\section{Vitamin C}

Retensi vitamin C merupakan ketahanan vitamin $\mathrm{C}$ dalam sari buah jeruk siam untuk terdegradasi apabila disimpan pada kondisi tertentu. Retensi vitamin C dapat ditunjukkan dengan perubahan (penurunan) kadar vitamin $\mathrm{C}$ selama penyimpanan

Data pada Tabel 4 diplotkan ke dalam kurva linear dan exponensial untuk menentukan orde reaksi yang digunakan. Dari kurva tersebut didapat bahwa nilai $\mathrm{R}^{2}$ tertinggi terdapat pada 
kurva linear yaitu orde nol. Dari kurva linear orde nol didapat persamaan garis terhadap semua perlakuan dan suhu yang sudah ditentukan. Dari persamaan tersebut dapat dihitung nilai $\mathrm{k}$.

Tabel 4. Penurunan kadar vitamin c jeruk siam dengan variasi suhu penyimpanan

\begin{tabular}{|c|c|c|c|}
\hline \multirow{2}{*}{ Hari Penyimpanan } & \multicolumn{3}{|c|}{ Variasi Suhu Penyimpanan } \\
\cline { 2 - 4 } & Suhu $10{ }^{\circ} \mathrm{C}$ & Suhu $15^{\circ} \mathrm{C}$ & Suhu $28{ }^{\circ} \mathrm{C}$ \\
\hline hari 0 & 19,36 & 19,36 & 19,36 \\
\hline Hari 3 & 19,00 & 18,56 & 17,60 \\
\hline hari 6 & 16,72 & 15,84 & 14,96 \\
\hline hari 9 & 14,96 & 12,14 & 11,61 \\
\hline hari 12 & 10,03 & 9,68 & 9,36 \\
\hline hari 15 & 9,50 & 8,98 & 8,50 \\
\hline hari 18 & 8,80 & 8,27 & 6,00 \\
\hline hari 21 & 6,51 & 5,28 & Busuk \\
\hline hari 24 & 4,75 & 4,10 & \\
\hline
\end{tabular}

\section{Penentuan Umur Simpan Jeruk Siam Berdasarkan Vitamin C}

Berdasarkan data penurunan kandungan vitamin c, persamaan orde 0 dan ordo 1 yang dihasilkan dirincikan dalam Tabel 5. Kedua jenis persamaan menunjukkan bahwa semakin tinggi suhu penyimpanan nilai konstanta laju rekasi (k) ini juga semakin besar. Hal ini menjelaskan bahwa reaksi penurunan vitamin pada penyimpanan suhu tinggi lebih besar dari pada penyimpanan suhu rendah. Fenomena tersebut dapat dilihat dari kedua jenis persamaan baik ordo 0 atupun ordo 1 .

Tabel 5. Persamaan orde 0 dan orde 1 untuk penurunan vitamin jeruk siam selama penyimpanan

\begin{tabular}{|c|c|c|}
\hline Suhu Penyimpanan $\left({ }^{0} \mathrm{C}\right)$ & Orde 0 & Orde 1 \\
\hline 28 & 0,9846 & 0,9799 \\
\hline 15 & 0,9693 & 0,964 \\
\hline 10 & 0,9862 & 0,9799 \\
\hline
\end{tabular}

Diketahui bahwa ordo reaksi yang digunakan adalah orde nol dikarenakan orde nol memiliki nilai koefisien determinasi terbesar dari pada orde satu, maka selanjutnya dihitung nilai k konstanta kecepatan.

\section{Hubungan Umur Simpan dengan Temperatur}

Nilai umur simpan bisa didapat pada temperatur lainnya yaitu dengan cara menghubungkan umur simpan dengan temperatur. Nilai $\mathrm{k}$ yang telah diperoleh tersebut dihubungkan dengan temperatur menggunakan persamaan Arrhenius.

$\mathrm{K}=\mathrm{k}_{0} \mathrm{e}^{-\mathrm{Ea} / \mathrm{RT}}$

atau,

Ln k $=\ln$ ko- $\frac{E a}{R} \times \frac{1}{T}$

Grafik dari hubungan ln $\mathrm{k}$ sebagai koordinat y dengan $1 / \mathrm{T}$ sebagai absis $\mathrm{x}$, akan memberikan persamaan garis lurus $\mathrm{y}=\mathrm{a}+\mathrm{bx}$. Untuk ln $\mathrm{k}$ sama dengan a sedangkan untuk Ea/RT sama dengan b. pada persamaan Arrhenius nilai temperaturnya dalam skala derajat 
kelvin. Maka untuk mengubah temperatur derajat celcius $\left({ }^{0} \mathrm{C}\right)$ ke kelvin $\left({ }^{0} \mathrm{k}\right)$ maka harus ditambahkan dengan 273 Dari grafik hubungan ln k dan 1/T

Dari grafik hubungan ln $\mathrm{k}$ dan 1/T diperoleh persamaan garis, sebagai berikut

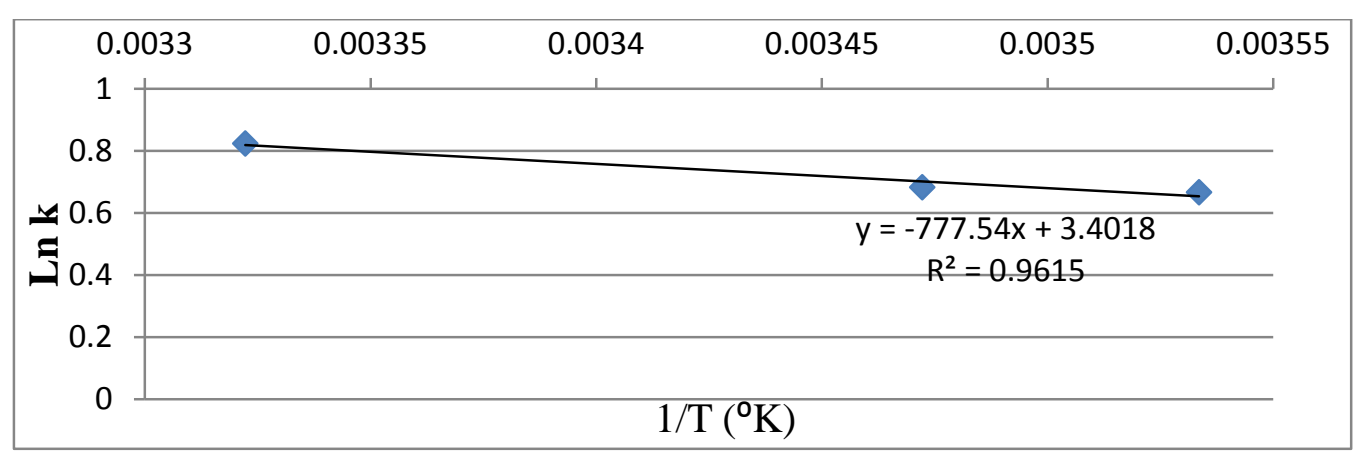

\section{Simulasi Model Pendugaan Umur Simpan}

persamaannya dapat digunakan untuk menghitung nilai $\mathrm{k}$ masing-masing perlakuan suhu penyimpanan lain yang berbeda. Maka dengan demikian dapat dihitung umur simpan jeruk siam dari semua perlakuan penyimpanan sesuai dengan suhu yang ditentukan.

$$
\begin{array}{ll}
\text { Ln k } & =-777.54(1 / \mathrm{T})-3.4018 \\
\mathrm{Ln} \mathrm{k} 0 & =3.4018 \\
\mathrm{~K} 0 \quad=30.01808
\end{array}
$$

Model k $=30.01808 \mathrm{e}^{-777.54(1 / \mathrm{T})}$

Maka, $\ln \mathrm{k}=(\mathrm{Ea} / \mathrm{R}) / \mathrm{T}+\ln \mathrm{ko}$

Setelah didapatkan nilai $\mathrm{k}$ dan $\ln \mathrm{k}$ seperti pada Lampiran 8 selanjutnya dilakukan perhitungan umur simpan menggunakan persamaan :

$\mathrm{A}=\mathrm{Ao}-\mathrm{kt} \longrightarrow \mathrm{t}=\frac{A o-A}{k}$

Maka diperoleh $\mathrm{t}$ (umur simpan)

Nilai energi aktivasi diperoleh dengan menggunakan persamaan Arrhenius yang didapatkan dari kelima persamaan. Dari persamaannya diketahui bahwa nilai Ea/R adalah 777.54. untuk mencari nilai Ea maka nilai tersebut dikalikan dengan konstanta gas $\mathrm{R}$ sebesar $1,986 \mathrm{kal} / \mathrm{mol}^{0} \mathrm{~K}$, Sehingga diperoleh nilai energi aktivasinya sebagai berikut:

$$
\begin{array}{cc}
\mathrm{Ea} & =777.54 \times \mathrm{R} \\
= & 1544.194 \mathrm{kal} / \mathrm{mol}
\end{array}
$$

\section{Model Pendugaan Laju Reaksi Penurunan Kandungan Vitamin C Jeruk Siam Selama Penyimpanan}

Setelah didapat nilai k maka selanjutnya untuk mendapatkan model dari penyimpanan setiap perlakuan suhu yaitu mencari model pendugaan laju penurunan mutu buah jeruk siam selama penyimpanan. Didapatkan nilai Ln k0 dan nilai k0. Nilai k0 merupakan Exponensial Ln k0 maka didapatkan modelnya sebagai berikut :

Dimana : Ln K0 = 3.4018 k0 = 30.01808 dan Ea/R $=1544.194 \mathrm{kal} / \mathrm{mol}$

Sehingga modelnya : $\mathrm{k}=30.01808$ e-777.54(1/T)

Hasil model pendugaan laju penurunan mutu buah jeruk siam menunjukkan bahwa semakin tinggi suhu penyimpanan maka semakin cepat terjadi peunurunan mutu kandungan vitamin $\mathrm{C}$ jeruk

\section{Validasi Model Pendugaan Kndungan Vitamin C Jeruk Siam Selama Penyimpanan}


Validasi model dapat dilakukan dengan membandingkan antara data yang diperoleh pada percobaan di laboratorium (data aktual) dengan data yang dihasilkan dari model, Dibawah ini merupakan hubungan antara vitamin $\mathrm{C}$ aktual dengan vitamin $\mathrm{C}$ model pada penyimpanan suhu $10{ }^{\circ} \mathrm{C}, 15{ }^{\circ} \mathrm{C}$ dan $28{ }^{\circ} \mathrm{C}$. diketahui bahwa vitamin $\mathrm{C}$ aktual dengan vitamin $\mathrm{C}$ model pada suhu $10{ }^{\circ} \mathrm{C}$ memiliki nilai koefisien determinasinya 0.93 yang menunjukkan tingkat hubungannya sangat kuat. Pada suhu $15{ }^{\circ} \mathrm{C}$ memiliki nilai koefisien determinasinya 0.96 yang menunjukkan tingkat hubungannya sangat kuat. Pada suhu $28{ }^{\circ} \mathrm{C}$ memiliki nilai koefisien determinasinya 0.97 yang menunjukkan tingkat hubungannya sangat kuat

\section{Hubungan Konstanta Laju Penurunan Mutu Jeruk Siam Dengan Suhu Penyimpanan}

Pada buah-buahan dalam proses penyimpanan akan terjadi penurunan mutu yang berhubungan erat dengan laju penurunan kualitas dari buah jeruk tersebut. Konstanta laju penurunan mutu merupakan nilai laju penurunan suatu bahan menuju kerusakan dalam proses penyimpanan. Sehingga semakin tinggi nilai konstanta laju penurunan mutu maka buah akan cepat terjadi kerusakan yang mengakibatkan penurunan mutu buah akan cepat terjadi kerusakan yang mengakibatkan penurunan mutu buah dan masa simpan buah semakin kecil (Puri, 2013).

Besar kecilnya konstanta laju penurunan mutu buah jeruk siam sangat dipengaruhi oleh suhu penyimpanan tersebut. Dari hasi model dapat dilihat semakin kecil suhu yang digunakan untuk penyimpanan maka konstanta laju penurunannya semakin kecil, begitu juga sebaliknya. Semakin tinggi suhu dalam penyimpanan maka konstanta laju penurunan mutu buah semakin tinggi. Dari hasil penelitiandapat disimpulkan bahwa suhu $10{ }^{\circ} \mathrm{C}$ pada penyimpanan jeruk siam lebih bagus dari pada suhu $28{ }^{\circ} \mathrm{C}$ dan suhu $15^{\circ} \mathrm{C}$.

\section{Simulasi Umur Simpan Dengan Model}

Pendugaan umur simpan dengan model dapat diaplikasikan untuk mengetahui berapa lama umur penyimpanan suhu komoditi dalam suhu yang berbeda-beda (Puri, 2013). Berdasarkan hasil penelitian, simulasi model didapatkan penyimpanan jeruk siam pada suhu 28 ${ }^{0} \mathrm{C}$ yaitu 13 hari dengan nilai koefisien determinasinya 0,97 , suhu $15{ }^{\circ} \mathrm{C}$ yaitu 14 hari dengan nilai koefisien determinasinya 0,96 , suhu $10{ }^{\circ} \mathrm{C}$ yaitu 15 hari dengan nilai koefisien determinasinya 0,93 .

\section{KESIMPULAN DAN SARAN}

Persentase susut bobot tertinggi dialami oleh jeruk siam yang disimpan pada suhu dingin $10^{\circ} \mathrm{C}$ dan suhu $15^{\circ} \mathrm{C}$ yaitu $11,57 \%$ pada penyimpanan hari ke- 12 . Tingkat kekerasan tertinggi pada suhu penyimpanan $10{ }^{0} \mathrm{C}$ yaitu $2.09 \mathrm{Kg} / \mathrm{cm}^{2}$. Suhu $15{ }^{0} \mathrm{C}$ mengalami kenaikan total padatan terlarut paling tinggi hingga $9,70 \%$ brix.

Secara keseluruhan skor tertinggi untuk pengujian organoleptik diberikan oleh panelis pada suhu $15^{\circ} \mathrm{C}$

Diperoleh model pendugaan laju penurunan mutu jeruk siam selama penyimpanan yaitu $\mathrm{k}=30.01808 \mathrm{e}^{-777.54(1 / \mathrm{T})}$.

Hasil simulasi model didapatkan penyimpanan jeruk siam pada suhu $28{ }^{\circ} \mathrm{C}$ yaitu 13 hari dengan nilai koefisien determinasinya 0,97 , suhu $15^{\circ} \mathrm{C}$ yaitu 14 hari dengan nilai koefisien determinasinya 0,96 , suhu $10{ }^{\circ} \mathrm{C}$ yaitu 15 hari dengan nilai koefisien determinasinya 0,93 


\section{DAFTAR PUSTAKA}

Fellow A P 2000. Food Procession Technology, Principles and Practise.2nd ed. Woodread.Pub.Lim. Cambridge. England. Terjemahan Ristanto.W dan Agus Purnomo.

Helmiyesi, R.B. Hastuti dan E. Prihastanti. 2008. Pengaruh lama penyimpanan terhadap kadar gula dan vitamin $\mathrm{C}$ pada buah jeruk siam (Citrus nobilis var. microcarpa).Buletin Anatomi dan Fisiologi. 2 : 33-37.

Kusnandar, F. 2006. Modul pelatihan pendugaan dan pengendalian masa kadaluarsa bahan dan produk pangan. Institut Pertanian Bogor, Bogor.

Puri, M. A. 2013. Pendugaan Umur Simpan Jagung Manis Berdasarkan Kandungan Total Padatan Terlarut Dengan Model Arrhenius. Skripsi. Program Studi Teknik Pertanian, Fakultas Pertanian, Universitas Siah Kuala, Banda Aceh.

Rukmana, R dan Y. Y. Oesman. 2003. Usaha Tani Jeruk Keprok. CV. Aneka Ilmu, Semarang. Syarief, R dan H. Hariyadi. 1993. Teknologi Penyimpanan Pangan. Penerbit ARCAN, Bogor. Zulkarnain. 2014. Dasar-Dasar Holtikultura. PT. Bumi Aksara, Jakarta. 